\title{
Anthropometric Characteristics of Elite Rhythmic Gymnasts
}

\author{
Características Antropométricas de Gimnastas Rítmicas de Elite \\ Enrique Arriaza*; Carolina Rodríguez ${ }^{* *}$; Claudia Carrasco ${ }^{* * * *}$; Claudia Mardones $^{* * *}$; \\ Luis Niedmann ${ }^{* * * * *}$ \& Antonio López-Fuenzalida ${ }^{* * * * * *}$
}

ARriazA, E.; RODRÍGUEZ, C.; CARRASCO, C.; MARDONES, C.; NIEDMANN, L. \& LÓPEZ-FUENZALIDA, A. Anthropometric characteristics of elite rhythmic gymnasts. Int. J. Morphol., 34(1):17-22, 2016.

SUMMARY: The main aim of this study was to identify the morphological characteristics, to determine the tendency in the physical structure, differences and similarities according to categories based on age of the Chilean team of Rhythmic Gymnastics. We performed an anthropometric analysis of 60 gymnasts, fractioned by categories: preschoolers and schoolers $(n=11)$, junior $(n=28)$ and senior $(n=21)$. The anthropometric analysis was determined based on the study of the body composition, through pentacompartimental fractionation method (Kerr), somatotype (Heath \& Carter) and the body mass index (Quetelet). The results showed significant differences between preschoolers and schoolers and higher categories (junior and senior) in the general anthropometric variables of body mass, height and BMI. Regarding the body composition, we only found significant differences in the percentage of muscle mass between the preschoolers and schoolers when being compared with the other two categories. In the study of somatotype, the prevalence of ectomorphic categorization was only found in the preschoolers and schoolers (meso-ectomorph), while in the junior category a mesomorph-ectomorph somatotype was observed and a central type in the senior category. We conclude that the morphology of the selected Chilean Rhythmic gymnastics depends on the category, as observed in the anthropometric characteristics related to the body composition and somatotype. Therefore, this factor is not useful in establishing a clearer tendency in the morph structure for this sport at a national level.

KEY WORDS: Rhythmic gymnastics; Kinanthropometry; Age categories.

\section{INTRODUCTION}

Morphological and physiological characteristics in contemporary sport (Claesses et al., 1999) influence both in sport success (Sedeaud et al., 2014) and in talent identification (Russel, 1987). In Rhythmic Gymnastics (RG) the constitutive physical aspects of the athlete play a major role from the choice of young talents (Sedeaud et al.; Miletic et al., 2004; Hume et al., 1993) until developing into elite gymnastics. The morphological factor is one of the basic factors for success (Di Cagno et al., 2008), as well as the psychological behavior (Sedeaud et al.; Di Cagno et al., 2009), food (D'Alessandro et al., 2007), age and maturity (Frish et al., 1981; Tringali et al., 2014).

Morphostructural characteristics of RG athletes are determined by different factors, such as genetic aspects (Tringali et al.), training level at early ages (Theodoropoulou et al., 2005; Misigoj-Durakovic, 2012), and specific nutritional plans (Sands et al., 2003), which while favouring optimum physical characteristics (Douda et al., 2008) can also be associated to alterations in the sexual maturity (Frisch et al.; Georgopoulos et al., 1999; Ávila-Carvalho et al., 2013; Maïmoun et al., 2014).

Specificity and intensity of training in RG along the growth period, generates alterations both at a cardiovascular system and muscle-skeleton level (Douda et al., 2008), as well as determining the particular morphological characteristics for this sport (Malina, 1994; Beunen et al., 1999), showing low levels of body fat and a morphological orientation towards relative linearity, which translates into a ectomorph-predominant somatotype (Claessens et al.), which in turns is related to high levels of relative strength (Malina et al., 2004).

It is in this context, and based on the understanding gained in studying the performance-oriented physical body

* Center of Advanced Studies and Faculty of Science on Physical Activity and Sport. Universidad de Playa Ancha, Valparaíso, Chile.

** Pedagogy Program in Physical Education, School of Education. Universidad Viña del Mar, Viña del Mar, Chile.

**** Analysis and Sport Training Planning Laboratory. Universidad de Playa Ancha, Valparaíso, Chile.

***** Exercise Physiology Laboratory, High Performance Center, Santiago, Chile.

${ }^{* * * * * *}$ School of Medicine. Faculty of Medicine. Pontificia Universidad Católica de Chile, Santiago, Chile. 
shape in these athletes, a morphological evaluation among the Chilean Team of Rhythmic Gymnastics in the different categories was carried out, in order to identify their characteristics, as well as determining the trends in physical structure, differences and similarities among the categories of age, and also recognize whether the Chilean team share the same body morphology with similar teams at a global level.

\section{MATERIAL AND METHOD}

Participants. The population under study is the high level rhythmic gymnastics girls chosen for the Chilean national team grouped by age categories: preschoolers and schoolers (from 9 to 12), junior (from 13 to 15) and senior (from 16 to 19). The sample considered all 60 girls chosen according to their categories: preschoolers and schoolers $n=11(10.6 \pm 1.1$ years old $)$; junior $n=28(13.7 \pm 0.8$ years old $)$ y senior $n=21$ (17.0 \pm 1.1 years old). The study was carried out upon the authorization of the Escuela de Talentos de Gimnasia Rítimica Deportiva de Chile (School of Rhythmic Gymnastics Talents of Chile) and was based on the voluntary participation of the athletes supported by a document signed by them or their legal tutors.

Data Collection and instruments. Seventeen anthropometric variables were used based on the indications, assessment and recommendations from the International Society for the Advancement of Kinanthropometry Advance (Marfell-Jones et al., 2006). The variables used were: a) basic weight $(\mathrm{kg})$ and height $(\mathrm{cm}), \mathrm{b})$ skin folds: triceps, subscapularis, supraspinatus, abdomen, thigh and calf c) body diameters $(\mathrm{cm})$ : humerus and femur, $\mathrm{d}$ ) body perimeters $(\mathrm{cm})$ : relaxed arm, fully contracted arm, forearm, thorax, rip, mid-thigh and calf. Data were collected at the Centro de Alto Rendimiento de Santiago de Chile (Centre for High Performance of Santiago, Chile)

Both choosing and managing the instruments used for the evaluation of the anthropometric variables was based on the proposals offered by ISAK. The following instruments were used for measurement: scale (Seca 769) $100 \mathrm{~g}$ accuracy, portable stadiometer (Seca 217) millimetric accuracy; anthropometric tape (Rosscraft); straight anthropometre (Rosscraft) millimetre accuracy; plicometre (Harpenden) 0.2 millimetric accuracy. Measurements were carried out always by the same anthropometrist; a $0.93 \%$ technical error was observed in the variables assessed.

Body Mass Index was then identified according to the formula proposed by Adolphe Quetelet - Weight (kg) /
Hight $^{2}$ (m) (Eknnoyan, 2008). Estimation of the muscular and fat body mass was carried out through body fractionation method proposed by Kerr (1988), but for somatotype identification, and the endomorphic, mesomorphic and ectomorphic components and its graphic representation through the somatochart, the anthropometric method of Heath and Carter (Carter \& Heath, 1990) was used.

Statistical Analysis. For the statistical treatment and the presentation of the data, a descriptive and inferential statistics was applied. Means and confidence intervals were determined for each variable. Prior to the application of comparison tests to the variables, a Shapiro-Wilk data distribution test was applied, determining the use of the Kruskal-Wallis test with a Dunn's multiple comparison post hoc test. An a value $<0.05$ was adopted in all case. Statistical analysis was performed using the STATA 13.0 program.

\section{RESULTS}

A progressive increase in all variables involved was appreciated (Table I). As the athletes grew, significant differences were evidenced in the body mass, height, and BMI between the preschoolers and schoolers when compared to the older categories (junior and senior). This situation was not observed when comparing the variables within the same category. Significant differences were observed in the percentage of muscle mass only when comparing the preschoolers and schoolers group against the other age categories. No significant differences were seen in the percentage of fat mass among these age categories (Table II).

There was a clear prevalence of the ectomorph component only in sport groups from the preschoolers and schoolers (Meso - ectomorph classification) (Fig. 1), while in the junior category a balance was found between the mesomoph and ectomorph component (Mesomorph ectomorph classification). On the other hand, senior gymnasts category had a balance between the three components of somatotype (central classification) (Figs. 2 and 3). Preschoolers and schoolers category showed significantly lower values in endomorph compared to the other two categories. But in the ectomorph component, preschoolers and schoolers showed higher values when compared against the other categories. However, this difference was significant only when comparing the younger aged against the older ones. Juniors presented a higher value in the mesomorph component compared to the other two (Figs. 1-4) although these differences were not significant among the groups. 
ARRIAZA, E.; RODRÍGUEZ, C.; CARRASCO, C.; MARDONES, C.; NIEDMANN, L. \& LÓPEZ-FUENZALIDA, A. Anthropometric characteristics of elite rhythmic gymnasts. Int. J. Morphol., 34(1):17-22, 2016

Table I. Basic anthropometric variables values in the athletes by age group.

\begin{tabular}{llll}
\hline & \multicolumn{1}{c}{$\begin{array}{c}\text { Pre-schoolers / schoolers } \\
(\mathbf{n = 1 1})\end{array}$} & \multicolumn{1}{c}{$\begin{array}{c}\text { Junior } \\
(\mathbf{n = 2 8})\end{array}$} & \multicolumn{1}{c}{$\begin{array}{c}\text { Senior } \\
(\mathbf{n = 2 1})\end{array}$} \\
\hline Weight $(\mathrm{kg})$ & $29.85[27.20-32.49]^{* * *}$ & $47.02[44.61-49.13]$ & $52.06[49.46-54.57]$ \\
Height $(\mathrm{cm})$ & $138.57[134.01-143.14]^{* * *}$ & $156.70[154.23-158.94]$ & $160.87[157.88-163.86]$ \\
BMI $(\mathrm{kg} / \mathrm{m} 2)$ & $15.49[14.71-16.29]^{* *}$ & $19.09[18.42-19.71]$ & $20.12[19.29-20.94]$ \\
\hline
\end{tabular}

Results as shown as mean and confidence intervals $(95 \%)$ * $\mathrm{p}<0.01$ against Junior. $* * \mathrm{p}<0.01$ against Senior.

Table II. Body constitution variables values of the athletes by age group.

\begin{tabular}{lccc}
\hline & $\begin{array}{c}\text { Pre-schoolers / schoolers } \\
(\mathbf{n = 1 1})\end{array}$ & $\begin{array}{c}\text { Junior } \\
(\mathbf{n = 2 8})\end{array}$ & $\begin{array}{c}\text { Senior } \\
(\mathbf{n = 2 1})\end{array}$ \\
\hline Muscular mass $(\%)$ & $36.65[34.88-38.44]^{\circ} * *$ & $39.87[38.80-41.24]$ & $40.61[38.96-42.25]$ \\
Fat mass $(\%)$ & $29.58[27.71-31.44]$ & $31.20[29.40-32.50]$ & $30.51[28.96-32.06]$ \\
\hline Results as shown as mean and confidence intervals $(95 \%){ }^{\circ}{ }^{\circ}<0.05$ against Junior. $* * \mathrm{p}<0.01$ against Senior.
\end{tabular}

Table III. Somatotype components values of the athletes by age group.

\begin{tabular}{lccc}
\hline & $\begin{array}{c}\text { Pre-schoolers / schoolers } \\
(\mathbf{n = 1 1})\end{array}$ & $\begin{array}{c}\text { Junior } \\
(\mathbf{n = 2 8})\end{array}$ & $\begin{array}{c}\text { Senior } \\
(\mathbf{n = 2 1})\end{array}$ \\
\hline Endomorph & $1.7[1.4-2.0]^{* * *}$ & $2.7[2.4-3.1]$ & $2.9[2.6-3.1]$ \\
Mesomorph & $3.3[2.9-3.7]$ & $3.5[3.2-3.8]$ & $3.4[3.0-3.8]$ \\
Ectomorph & $4.2[3.6-4.8]^{* *}$ & $3.3[3.0-3.6]$ & $3.0[2.5-3.5]$ \\
\hline
\end{tabular}

Results as shown as mean and confidence intervals (95\%).* $p<0.01$ against Junior. ** $\mathrm{p}<0.01$ against Senior.

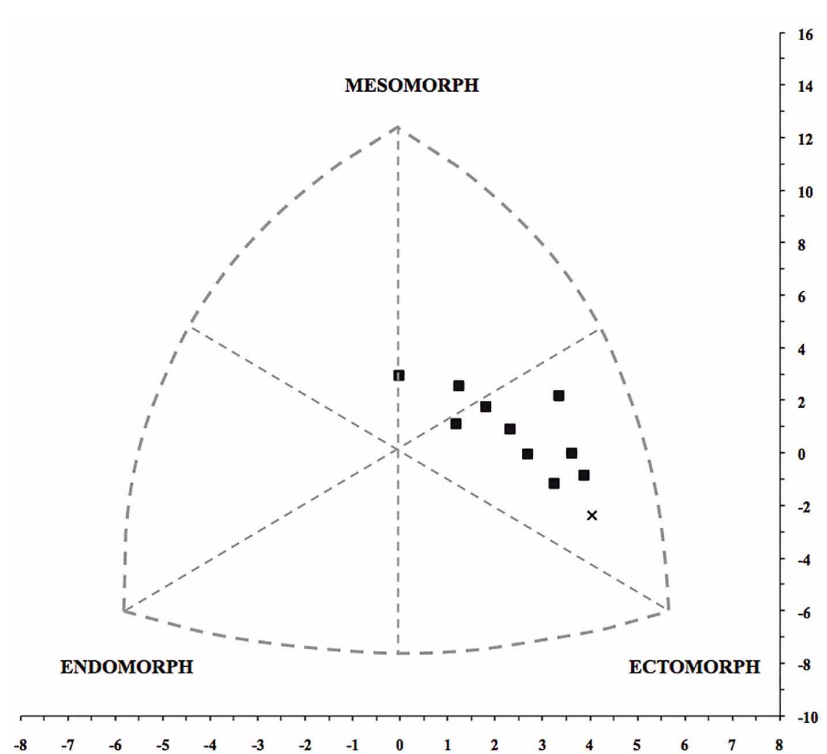

Fig. 1. Pre-schoolers/schoolers athletes Somatochart.

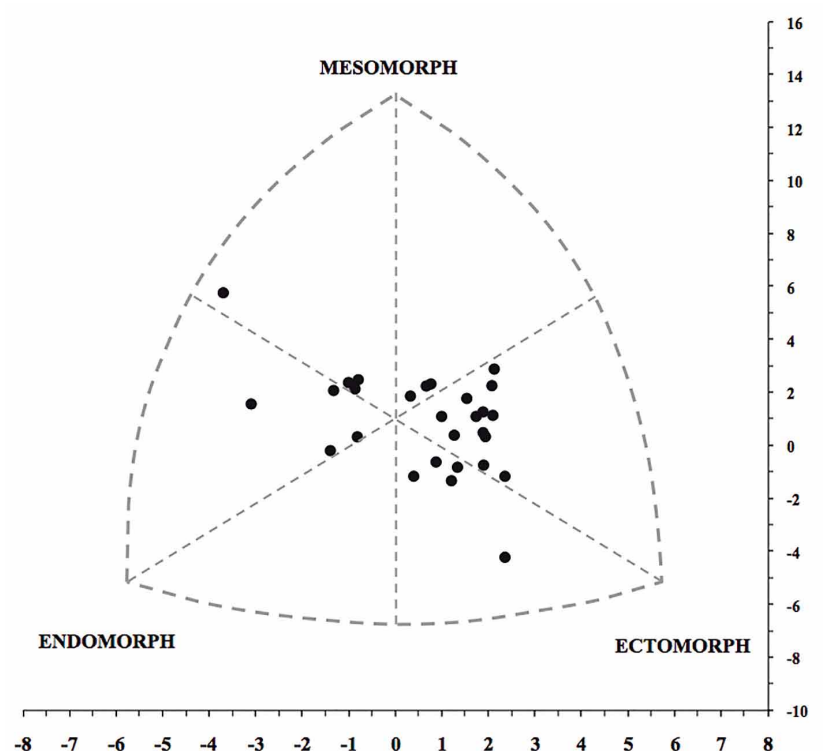

Fig. 2. Junior athletes Somatochart. 


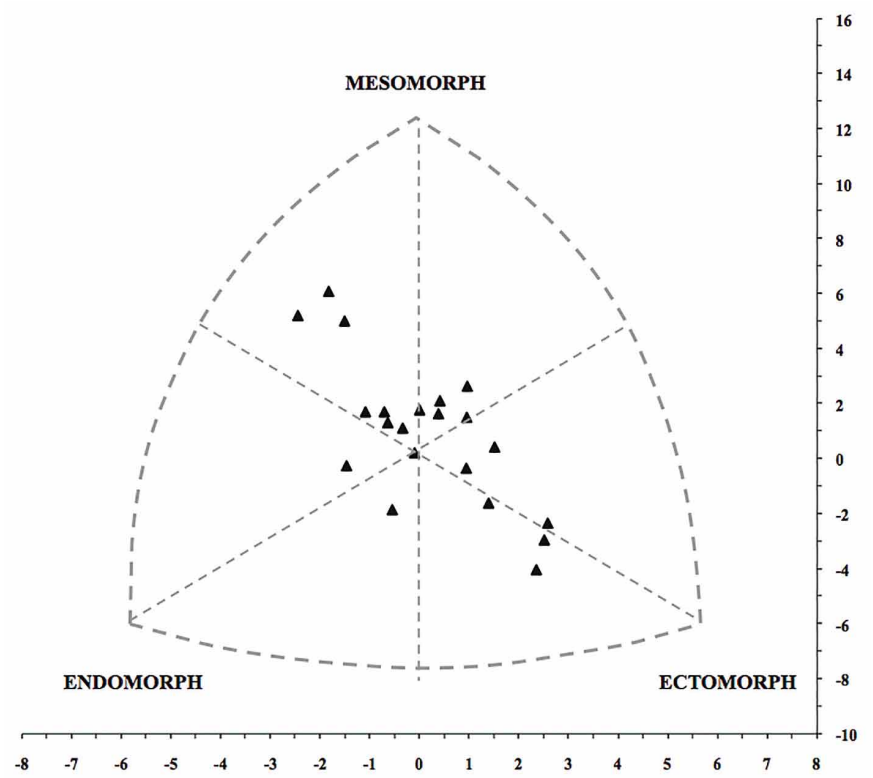

Fig. 3. Senior athletes Somatochart.

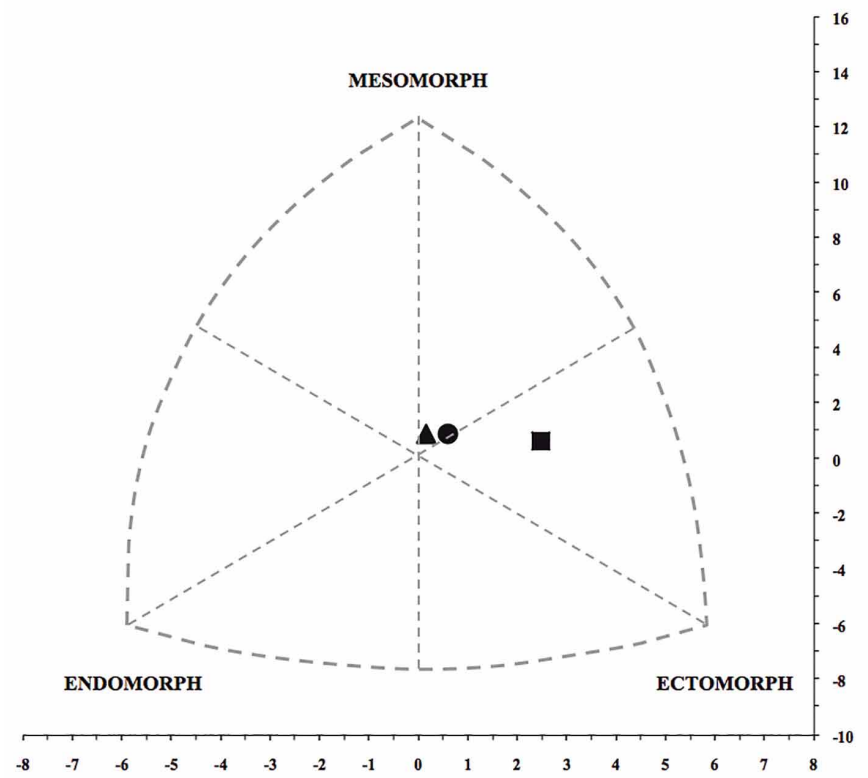

Fig. 4. Somatochart of all athletes assessed (quadrate: pre-schoolers/ schoolers athletes; circle: junior athletes; triangle: senior athletes).

\section{DISCUSSION}

Rhythmic Gymnastics is one of the sports in which anthropometric characteristics loom large (Miletic et al., 2004), due to an early specialisation, rigorous and specific training and the incidence of morphologic and phenotypic factors in performance. Nevertheless, the mere fact of starting with an early specialisation implies changes in growing processes, both in menarche and intense training (Georgopoulos et al.; Maïmoun et al.). In fact, literature shows differences between elite athletes and general population, which can also be linked to genetics associated to an early start (Tringali et al.; Ávila-Carvalho et al.).

Along with flexibility, explosive strength, aerobic capacity and anaerobic metabolism, anthropometric characteristics of the athletes prove to be basic for the routine practices in the discipline (Douda et al.), with translates into a better performance (Di Cagno et al., 2008, 2009).

Basic variables of weight, height, and BMI, differences were significant just by comparing preschoolers and schoolers against the older age groups. This behaviour can be associated to the growing stage of the athletes (Georgopoulos et al.; Ávila-Carvalho et al.; Maïmoun et al.; Hume, et al.). It is interesting to pinpoint the differences in the behaviour of these variables in the categories of the Chilean team when compared to the data from other elite athletes found in the literature (Douda $e t$ al.), in which 15 elite athletes were featured with an average age (13.41 \pm 1.62 years old) corresponding to the junior category of the Chilean team, as well as weight and height: $35.60 \pm 5.46 \mathrm{~kg}$ and $151 \pm 0.6 \mathrm{~cm}$ respectively, whose values are different from those of the Chilean team at the same age group; $156.70 \pm 6.15 \mathrm{~cm}$ high and $47.02 \pm 5.89 \mathrm{~kg}$ in weight for the total body mass, showing $12 \mathrm{~kg}$ difference between the means of body weight. Similar differences in the basic morphological variables are seen in Di Cagno et al. (2008), in which, the morphological data of the same variables for the Italian rhythmic gymnastics team in 2002, show that weight and height for juniors is $40.4 \pm 6.9 \mathrm{~kg}$ and $155.7 \pm 8.9 \mathrm{~cm}$. Nevertheless, additional data are found in the BMI of the athletes with values of $16.5 \pm 1.4 \mathrm{~kg} / \mathrm{m}^{2}$, while the same category Chilean team is $19.09 \pm 1.69 \mathrm{~kg} / \mathrm{m}^{2}$, showing how the difference in body mass can affect the Chilean performance, particularly if we consider that the same category of the Italian Team was awarded an Olympic Medal at the Athens Olympic Games in 2004. The same authors mention the behavior of the same variables for the senior Italian team in 2002, whose values are 45.9 \pm 4.9 $\mathrm{kg}$ of total body mass and $163 \pm 6.0 \mathrm{~cm}$ high, while the Chilean team at the same category showed 52.06 \pm 5.73 $\mathrm{kg}$ and $160.87 \pm 6.57 \mathrm{~cm}$ for weight and height respectively. As it can be seen in the latest data, the main difference between these national teams lies in the body mass showing a difference in the means of $6 \mathrm{~kg}$ app. translating into a higher BMI in the Chileans compared to the Italians (20.12 \pm 1.89 vs. 17.1 \pm 1.3$)$. Vernetta et al. (2011) with data from the Andalusian team in schoolers (9 to 11) and older 
(12 to 15), equivalent to the Chilean team would be the categories of preschoolers and schoolers and junior respectively, showed no morphological difference in the younger categories (BMI $15.51 \pm 0.92 \mathrm{~kg} / \mathrm{m}^{2}$ for the Andalusian team vs. $15.49 \pm 1.16 \mathrm{~kg} / \mathrm{m}^{2}$ for the Chilean athletes). However, in the higher category (junior) differences can be seen in the BMI $17.04 \pm 1.54 \mathrm{~kg} / \mathrm{m}^{2}$ for the Andalusian girls compared to the junior category values of the Chilean team. This difference also lies on weight, $7 \mathrm{~kg}$ app. (47.02 $\mathrm{kg}$ for the Chileans vs. $39.85 \mathrm{~kg}$ for the Andalusian team), despite the Chilean girls are higher than the Andalusian (156.70 vs. $151.67 \mathrm{~cm})$.

Based on the somatotype data from the Chilean team, significant differences are found endomorphically between the preschoolers and schoolers compared to the Junior and Senior categories; while in terms of the ectomorph component, only significant differences were identified when comparing preschoolers and schoolers with the senior category. This behavior in the somatotype component generates a different bio-typological classification among the categories, indicating that the younger category is Mesoectomorph, while the other two categories, junior and senior, had a Mesomorph - Ecto morph and central classification, respectively (see fig. 4). Interestingly, by contrasting these data against those shared by Vernetta et al., an inversion in the somatotype typification can be seen between categories similar to preschoolers and schoolers and junior, classified as Mesomorph-Ectomorph for the younger category (somatotype 1.81-3.69-3.70) and Meso - Ectomorph for the older category (somatotype 2.06-3.16-4.12). This accounts for a loss of the relative linearity in the Chilean team as categories grow in age, but the contrary case obtains for the Andalusian athletes.

Curiously, by analysing the morphological data, no differences are found in the mesomorph component of the somatotype. Notwithstanding, significant variations are seen in the percentage of body mass, while similar data are obtained when contrasting the endomorph component of the somatotype against the percentage of the fat mass in terms of the body constitution. However, while these studying methods for the morphostructure of the athletes can show certain relationship among components, it is not an obligation to find identical behaviours, particularly when understanding the intrinsic aspects of the somatotype study and the body constitution. This would evidence differences among variables, as the somatotype accounts only for the prevalence of a group of tissues over the other, which are enclosed within the terminology of endomorph, mesomorph and ectomorph components, while body constitution contemplates estimating the amount of specific mass and not prevalence of some over the others.
ARRIAZA, E.; RODRÍGUEZ，C.; CARRASCO, C.; MARDONES, C.; NIEDMANN, L. \& LÓPEZ-FUENZALIDA, A. Características antropométricas de gimnastas rítmicas de elite. Int. J. Morphol., 34(1):17-22, 2016.

RESUMEN: El objetivo principal de este estudio fue identificar las características morfológicas para determinar la tendencia de la estructura física, las diferencias y similitudes de acuerdo con las categorías basadas en la edad de la Selección Chilena de Gimnasia Rítmica. Se realizó un análisis antropométrico de 60 gimnastas, fraccionado por categorías: preescolares y escolares ( $\mathrm{n}$ $=11)$, junior $(\mathrm{n}=28)$ y senior $(\mathrm{n}=21)$. El análisis antropométrico se determinó en base al estudio de la composición corporal, a través del método de fraccionamiento pentacompartimental (Kerr), del somatotipo (Heath \& Carter) y el índice de masa corporal (Quetelet). Los resultados mostraron diferencias significativas entre los niños preescolares y escolares y las categorías superiores (junior y senior) en las variables antropométricas generales de masa corporal, altura e IMC. En cuanto a la composición corporal, sólo encontramos diferencias significativas en el porcentaje de masa muscular entre los preescolares y escolares, cuando se comparan con las otras dos categorías. En el estudio del somatotipo, la prevalencia de la categorización ectomórfica solamente se encontró en los niños preescolares y escolares (meso-ectomorfo), mientras que en la categoría junior se observó un somatotipo mesomorfoectomorfo y un tipo central en la categoría senior. En conclusión, la morfología de los seleccionados de gimnasia rítmica chilena depende de la categoría, como se observa en las características antropométricas, relacionados con la composición corporal y el somatotipo. Por lo tanto, este factor no es útil para establecer una tendencia clara en la estructura morfológica para este deporte a nivel nacional.

PALABRAS CLAVE: Gimnasia rítmica; Cineantropometría; Categorías de edad.

\section{REFERENCES}

Ávila-Carvalho, L.; Klentrou, P.; da Luz Palomero, M. \& Lebre, E. Anthropometric profiles and age at menarche in elite group rhythmic gymnasts according to their chronological age. Sci. Sports, 28(4):172-80, 2013.

Beunen, G. P.; Malina, R. M. \& Thomis, M. Physical Growth and Maturation of Female Gymnasts. In: Johnston, F. E.; Zemel, B. \& Eveleth, P. B. (Eds.). Human Growth in Context. London, Smith-Gordon, 1999. pp.281-9.

Carter, J. E. L. \& Heath, B. H. Somatotyping: Development and Applications. New York, Cambridge University Press, 1990.

Claessens, A. L.; Lefevre, J.; Beunen, G. \& Malina, R. M. The contribution of anthropometric characteristics to performance scores in elite female gymnasts. J. Sports Med. Phys. Fitness, 39(4):355-60, 1999. 
D'Alessandro, C.; Morelli, E., Evangelisti, I.; Galetta, F.; Franzoni, F.; Lazzeri, D.; Piazza, M. \& Cupisti, A. Profiling the diet and body composition of subelite adolescent rhythmic gymnasts. Pediatr. Exer. Sci., 19(2):215-27, 2007.

Di Cagno, A.; Baldari, C.; Battaglia, C.; Brasili, P.; Merni, F.; Piazza, M.; Toselli, S.; Ventrella, A. R. \& Guidetti, L. Leaping ability and body composition in rhythmic gymnasts for talent identification. J. Sports Med. Phys. Fitness, 48(3):341-6, 2008.

Di Cagno, A.; Baldari, C.; Battaglia, C.; Monteiro, M. D.; Pappalardo, A.; Piazza, M. \& Guidetti, L. Factors influencing performance of competitive and amateur rhythmic gymnastics-gender differences. J. Sci. Med. Sport, 12(3):411-6, 2009.

Douda, H. T.; Toubekis, A. G.; Avloniti, A. A. \& Tokmakidis, S. P. Physiological and anthropometric determinants of rhythmic gymnastics performance. Int. J. Sports Physiol. Perform., 3(1):41-54, 2008.

Douda, H.; Tokmakidis, S. \& Tsigilis, N. Effects of specific training on muscle strength and flexibility of rhythmic sports and artistic female gymnasts. Coach Sport Sci. J., 4(1):23-7, 2002.

Eknoyan, G. Adolphe Quetelet (1796-1874)--the average man and indices of obesity. Nephrol. Dial. Transplant., 23(1):47-51, 2008.

Frisch, R. E.; Gotz-Welbergen, A. V.; McArthur, J. W.; Albright, T.; Witschi, J.; Bullen, B.; Birnholz, J.; Reed, R. B. \& Hermann, $\mathrm{H}$. Delayed menarche and amenorrhea of college athletes in relation to age of onset of training. JAMA, 246(14):1559-63, 1981.

Georgopoulos, N.; Markou, K.; Theodoropoulou, A.; Paraskevopoulou, P.; Varaki, L.; Kazantzi, Z.; Leglise, M. \& Vagenakis, A. Growth and pubertal development in elite female rhythmic gymnasts. J. C. E. M., 84(12):4525-30, 1999.

Hume, P. A.; Hopkins, W. G.; Robinson, D. M.; Robinson, S. M. \& Hollings, S. C. Predictors of attainment in rhythmic sportive gymnastics. J. Sports Med. Phys. Fitness, 33(4):367-77, 1993.

Kerr, D. A. An anthropometric method for the fractionation of skin, adipose, muscle, bone and residual tissue masses in males and females age 6 to 77 years. M. Sc. Thesis. Burnaby, Simon Fraser University, 1988.

Maïmoun, L.; Georgopoulos, N. A. \& Sultan, C. Endocrine disorders in adolescent and young female athletes: impact on growth, menstrual cycles, and bone mass acquisition. J. Clin. Endocrinol. Metab., 99(11):4037-50, 2014.

Malina, R. M. Physical growth and biological maturation of young athletes. Exerc. Sport Sci. Rev., 22:389-433, 1994.

Malina, R. M.; Bouchard, C. \& Bar-Or, O. Growth, Maturation, and Physical Activity. $2^{\text {nd }}$ ed. Champaign, Human Kinetics, 2004.
Marfell-Jones, M.; Olds, T.; Stewart, A. D. \& Carter, L. International Standards for Anthropometric Assessment. Potchefstroom, International Society for the Advancement of Kinanthropometry (ISAK), 2006.

Miletic, D.; Katic, R. \& Males, B. Some anthropologic factors of performance in rhythmic gymnastics novices. Coll. Antropol., 28(2):727-37, 2004.

Misigoj-Durakovic, M. Anthropometry in Premenarcheal Female Esthetic Sports Athletes and Ballerinas. In: Preedy, V. R. (Ed.). Handbook of Anthropometry. Physical Measures of Human Form in Health and Disease. New York, Springer, 2012. pp.1817-36.

Russell, K. Gymnastic talent from detection to perfection. World identification systems for gymnastic talent. Montreal, Sport Psyche Editions, 1987. pp.151-9.

Sands, W. A.; Caine, D. J. \& Borms, J. Scientific Aspects of Women's Gymnastics. In: Borms, J.; Hebbelinck, M. \& Hills, A. P. (Eds.). Medicine and Sport Science. Vol. 45. Basel, Karger, 2003. pp.110-27.

Sedeaud, A.; Marc, A.; Shipman, J.; Schaal, K.; Danial, M.; Guillaume M.; Berthelot, G. \& Toussaint, J. Secular trend: morphology and performance. J. Sports Sci., 32(12):1146-54, 2014.

Theodoropoulou, A.; Markou, K. B.; Vagenakis, G. A.; Benardot, D.; Leglise, M.; Kourounis, G.; Vagenakis, A. G. \& Georgopoulos, N. A. Delayed but normally progressed puberty is more pronounced in artistic compared with rhythmic elite gymnasts due to the intensity of training. J. Clin. Endocrinol. Metab.,90(11):6022-7, 2005.

Tringali, C.; Brivio, I.; Stucchi, B.; Silvestri, I.; Scurati, R.; Michielon, G.; Alberti, G \& Venerando, B. Prevalence of a characteristic gene profile in high-level rhythmic gymnasts. $J$. Sports Sci., 32(14):1409-15, 2014.

Vernetta, M.; Fernández, E.; López-Bedoya, J.; Gómez-Landero, A. \& Oña, A. The relations between morphological profile and body esteem of Andalusian rhythmic gymnastics team. Motricidad. Eur. J. Hum. Mov., 26:77-92, 2011.

\section{Correspondence to:}

Dr. Enrique Arriaza Ardiles

Center of Advanced Studies and Faculty of Science on Physical Activity and Sport

Universidad de Playa Ancha

Valparaíso

CHILE

Email: earriazaa@gmail.com

Received: 13-02-2015

Aceppted: 18-11-2015 